\title{
Improving High-Tech Product Development through Communication Audits
}

\author{
Mirja Vaananen, Pekka Belt, Janne Harkonen, Matti Mottonen \\ University of Oulu, Oulu, Finland \\ Email: mirja.vaananen@oulu.fi
}

Received November 4, 2011; revised December 4, 2011; accepted December 12, 2011

\begin{abstract}
Functional communication is a necessity to succeed in high technology product development where projects typically are multi-site, multi-cultural, multi-technical, and products are complex. The aim of this study is to clarify what kind of process is suitable for assessing the effectiveness of communication in high-tech product development. Based on the literature analysis, a communication audit process is constructed and tested in five product development projects of different information and communication technology (ICT) companies. Based on test case experiences and analyses, this study proposes a streamlined communication audit process. An outcome of this paper is a streamlined communication audit process that provides benefits for companies, but does not burden the organisation unnecessarily. Managers of high-tech companies can utilise the developed process for enhancing communication in their product development.
\end{abstract}

Keywords: Communication; Employee Communication; Internal Communication; Communication Audit Methods; Productivity; Performance

\section{Introduction}

Product development plays a crucial role for high technology companies. Short product lifecycles, continuous launches of new products, and new technologies are typical for surviving in high-tech business [1]. In other words, product development is the life-blood for high technology companies [1-3].

In high-tech, product development projects are typically multi-site and multi-cultural [4,5]. Personnel can be involved in several simultaneous projects, while products are very complex [6,7]. In addition, projects are typically multi-technical involving professionals with different backgrounds [8]. All of these aspects make communication for assuring successful product development challenging.

Organising product development in ICT companies has some special features that shape communication systems of these organisations. For example, ICT product development projects typically involve a network of companies and subcontractors [9]. The personnel in product development projects are typically geographically distributed [4]. Even though the project may not be multisite, there are often many national cultures involved [5]. Additionally, there are several on-going projects in the product development, and the personnel maybe involved in several projects at the same time [6]. In ICT projects the product itself is complex (complex product structure
[7]), and may involve professionals with different backgrounds: e.g. software designers, electronics designers, mechanics designers, system designers (multi-technical projects) [8]. These aspects should be considered when planning a communication audit.

Both, internal and external communication is seen vital for successful business [10-12]. Several studies consider communication critical for project success [13-16]. Communication audits are used for exploring, examining, monitoring, and evaluating communication. Audits are used to reveal gaps in the communication process and to provide suggestions for improvements [17]. Typically audits consider communication as a process related to other organisational processes [18]. The results of organisational communication assessment, i.e. how the personnel view the organisation, management and strategic goals, can be used for strategic planning [19]. Communication audits can give feedback to management on how the communication process is perceived [20]. In addition, communication audits increase top managers' understanding of the effects of communication [21]. Ramsing [22] calls for more studies on project communication from strategic perspective.

Multiple methods are favoured for conducting communication audits. Zwije-Koning and de Jong [23] argue that, among the organisational communication audit literature, there is a lack of discussion of what kind of information can be sought through different methods used 
in communication audits. They state that triangulation is important but not sufficient requirement when selecting methods used in an audit. Previous literature has shown the advantages of both quantitative [24] and qualitative [25-27] methods. The most often used include interviews, surveys, focus groups, observations, network analyses, content analyses, communication diaries, and critical incident analyses. Typically, different methods are used to complement each other [19].

This study aims to clarify what kind of process is suitable for assessing the effectiveness of communication in high-tech product development. This study is constructive in nature. First, based on literature analysis, an audit process is constructed. Second, the constructed process is tested extensively in five product development projects of different information and communication technology (ICT) companies. Finally, conclusions are made and a streamlined communication audit process is proposed for the ICT sector's product development.

\section{Literature Review}

Communication audit process may involve different kind of methods. It is typical that the audit process includes surveys, interviews, seminars and organisational documentations [19]. However, all of these are not necessarily included in each audit, but audits emphasise different aspects [18].

Surveys are very popular methods used in communication audits. The most popular surveys are Communiaction Satisfaction Questionnaire (CSQ) by Downs and Hazen [28], ICA Audit Survey [29,30], and LTT audit questionnaire [31,32]. These surveys have contentual differences and they have distinct focuses. In addition, there are variations in the process how the required information is obtained for these surveys.

CSQ is a quantitative tool providing statistical data about employees' communication satisfaction [20]. In communication audits, CSQ is interested of perceived satisfaction, and is typically utilised to complement other methods [18].

ICA audit survey highlights receiving and sending information [29]. ICA survey highlights difference of currents status and desired state (e.g. amount of information received versus amount of desired). ICA audit survey can also be conducted as a web-based survey [30]. Goldhaber [30] reports many advantages of utilising online survey: it is easier for the auditor, giving responses is easier, responses are given faster and response rate is greater. Thus, using online survey may increase reliability of the survey.

LTT survey aims to study communication climate i.e. the perceived atmosphere of opinions and attitudes with a special interest on information seeking and computer information systems [31,32]. LTT communication audit includes an 11 step procedure and has a strong emphasis on enhancing organisational practices. Repeating the use of the same questionnaire enables comparing results over the years [31].

It is typical that audit processes include more than one method to collect and analyse data. For example, CSQ has been used in different kind of audit processes to supplement data gathered by e.g. interviews, critical incident technique, and network analysis. Zwije-Koning and de Jong [33] state that different methods provide different type information and thus using mixed methods supports making analysis and conclusions. An audit should have an aim to identify challenges and develop activities, resulting in a questionnaire, such as CSQ not to be adequate alone [20]. Using multiple methods supports the thinking of [34] on communication being a comprehensive issue.

Findings by Vos [21] support utilising seminars in the audit process as they promote creating a common understanding of improvement plans in the organisation. Focus group method can be realised as a seminar or a group interview. Using focus groups is one way of collecting qualitative data [35]. Advantages of focus groups include allowing communication concerning the topic [36]. Using an external auditor is seen to increase the validity of the audit process [21].

\section{Research Method}

This study is constructive in nature. First a literature review was conducted, covering both communication audits and special characteristics of new product development in the ICT sector. Based on the literature analysis, an audit process was constructed and extensively tested in five product development projects of different ICT companies. Finally, based on test case experiences and analyses, this study proposes a streamlined communication audit process for the ICT sector's product development. Figure 1 illustrates the research method utilised for this study.

The audit process contained a questionnaire that was developed utilising earlier research on communication audits, especially those of CSQ [28], ICA Audit Survey [29,30], and LTT audit questionnaire [31,32]. In addition, research done by Müller [37] and the Construction Industry Institute [38] were utilised.

The constructed audit process was tested in five high technology companies. The participating companies were selected based on them well representing the sector, including different type of actors. Table 1 presents the case

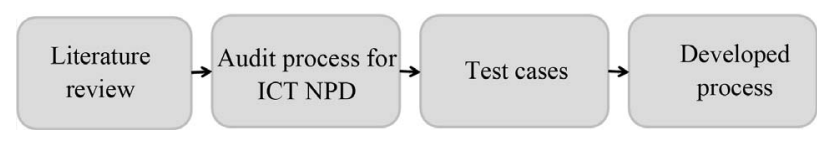

Figure 1. Research method. 
Table 1. Case companies.

\begin{tabular}{ccccc}
\hline & Industry sector & Project duration & Man-years & Persons involved \\
\hline I & Telecom software & 2 yrs & 150 & 270 \\
II & Telecommunication & $1 \mathrm{yr}$ & 50 & 130 \\
III & Software industry & $0.5 \mathrm{yrs}$ & 5 & 15 \\
IV & Electronics & $1 \mathrm{yr}$ & 0.5 & 20 \\
$\mathrm{~V}$ & Electronics & $2 \mathrm{yrs}$ & 20 & 26 \\
\hline
\end{tabular}

companies. Two (I and II) of the five high-tech companies are large global actors with tens of thousands of employees, and three others (III, IV and V) employ from 100 to 1000 people. All these companies have global operations, common nominator being offices in Finland.

The audit process was realised in one product development project in each participating company. The project durations varied from six months to two years, with personnel from fifteen to three hundred. However, all the projects were in an execution phase, making comparisons possible. In addition, a cross-case analysis was conducted and the results were discussed with the participating companies.

\section{Results and Discussion}

\subsection{Audit Process Created Based on Literature}

Based on earlier literature, this study developed an audit process for assessing and enhancing communication in the selected cases. The developed audit process utilises both quantitative and qualitative data collection methods. It was considered important that such a process would acknowledge the viewpoints of both management and employees in a versatile manner. On the other hand, the workload of participating employees was to be minimised. The process was designed to be managed by an external, or internal, process consultant. Figure 2 illustrates the communication audit process utilised in the case analyses. The audit process includes feedback loops. The background information obtained through analysing internal documents and interviews are to be used for formulating a survey and to direct the work of focus groups.

The purpose of the Initiation phase is to enable a smooth start. The second step, analysing existing docu- mentation, provides background information on official guidelines. The third step, thematic semi-structured interviews are used to obtain qualitative data on personnel's opinions. The fourth step, a web-based survey, is used to provide quantitative data for the auditing process. Focus group working is included to enhance dialog, and deepen information, within the organisation. The final step in the proposed audit process provides conclusions and proposes an action plan.

\section{1) Initiation}

Initiation phase aims at reaching a common understanding over the audit process, its goals and methods to be used. The roles and responsibilities of each participant are also clarified at this phase. For an external auditor, this phase enables obtaining an understanding over the organisation and its business. This phase determines the scope for auditing. Background information, including project type, size, duration and such, are documented to enable future analyses on whether development has occurred.

\section{2) Documents}

Analysing organisation's documentation provides information on official communication practices. Official documents are seen to define communication processes, media and data bases used. The documentation may include results of earlier surveys, project plan guidelines and any other documentation guiding project communications.

\section{3) Interviews}

The objectives for interviews include familiarising the auditor with essential current project communication practices. This information is also utilised to create a meaningful survey. Interviews can provide useful information as the interviewees' opinions may vary from the official truth presented in documentations.

\section{4) Survey}

Benchmarking previous surveys may provide a good starting point for building an effective questionnaire. There are some vital practical considerations, such as whether using a paper or electronic surveys, how big is the workload imposed on each respondent and what is the deadline for responses, etc. Respondents may give their responses individually, or be invited to meeting where the survey is filled. The audit processes trialled in this

\begin{tabular}{|c|c|c|c|c|c|}
\hline $\begin{array}{l}\text { Initiation } \\
\text {-Agreement on II } \\
\text { - contact persons } \\
\text { - research } \\
\text { objectives } \\
\text { - the project } \\
\text { to study }\end{array}$ & $\begin{array}{l}\text { Documents } \\
\bullet \text { Case } \\
\text { background } \\
\text { information } \\
\text { - Qualitative data } \\
\text { of current official } \\
\text { project } \\
\text { communication } \\
\text { practices }\end{array}$ & $\begin{array}{l}\text { Interviews } \\
\bullet \text { Case } \\
\text { background } \\
\text { information } \\
\text { - Qualitative data } \\
\text { of current project } \\
\text { communication } \\
\text { practices according } \\
\text { to interviewees }\end{array}$ & $\begin{array}{l}\text { Survey } \\
\bullet \text { Quantitative } \\
\text { data concerning } \\
\text { communication } \\
\text { challenges }\end{array}$ & $\begin{array}{l}\text { Focus group } \\
\text { Qualitative } \\
\text { data concerning } \\
\text { communication } \\
\text { challenges }\end{array}$ & $\begin{array}{l}\text { Conclusions } \\
\bullet \text { Data analysis and } \\
\text { interpretation } \\
\text { - Comparison to } \\
\text { - earlier results } \\
\text { - benchmarking } \\
\text { data } \\
\text {-Defining an } \\
\text { action plan }\end{array}$ \\
\hline
\end{tabular}

Figure 2. Communication audit process. 
study were conducted using a web-based questionnaire (ZEF Solutions), enabling the respondents to give their answers when most suitable for them. In addition, this reduces the required paper work, and provides the data in ready electronic form. The survey conducted is included in Appendix I.

\section{5) Focus group}

Focus group work enables deeper discussions on both survey results, and the true communication challenges encountered in the company. Discussions provide qualitative data on the strengths and weaknesses of the communication within the organisation, complementing quantitative data obtained through the survey.

Important for using the focus group method is considering the group composition. For the discussion to be fruitful there should be suitable number people with relevant backgrounds. A survey can easily cover a large number of people, but a functional focus group typically includes some 6 to 8 people [39]. The trialled audit processes focus group participants represented different roles: designers and other engineering personnel, supporting functions, e.g. quality support for the projects, and project management.

Focus group participants can bring forward issues they see important. However, it is beneficial if a process consultant assures the efficiency of the meeting, e.g. by guiding the discussion first to cover weaknesses and only after the potential solutions. Process consultant should not take a position on the topics to be covered.

\section{6) Conclusions and action plan}

In this phase, the data collected during the earlier phases is analysed. Process consultant makes conclusions on the results of previous phases and proposes an action plan for the company, e.g. for management group. It is also possible to compare any previously collected data, or results of earlier audits, against the results of the current audit. In addition, benchmarking audits from other companies may prove beneficial, if obtainable.

\subsection{Results on Testing the Process and Discussion}

The underlying message from the studied cases was that the exercise has a positive impact on the companies. The process itself was experienced to act as a medium for distributing information as some employees were not aware of all the documentation the companies had developed. However, from the perspective of companies, it would be desirable if the process was streamlined for improved efficiency.

Companies experienced kick-off meetings, in the initiation phase, beneficial to clarify the purpose and goals of the exercise. Utilising all documentation containing guidelines for communication, i.e. project plan templates, project communication plan templates, guidelines for using information systems and communication channels, proved beneficial. Interviews were experienced to provide useful knowledge over how, and to what extent, the existing documents were applied. However, in order to make the communication audit process more efficient, some elements of the beginning of the process can potentially be combined, while the benefits remain the same, i.e. initiation, documents, and interviews.

The survey was experienced as efficient and not to cause unnecessary workload. However, it is possible to streamline the survey further by removing overlapping questions. Response rate was appropriate and the results experienced interesting. The focus groups believed that the previous phases of the process were beneficial and making an action plan purely based on the survey would be challenging.

Different employee groups participating proved beneficial, providing versatile viewpoints. In addition, the process itself was experienced useful as information flowed between different groups. In general the audit process is seen to improve awareness over the significance of communication during new product development.

Figure 3 illustrates a streamlined process proposed based on case experiences.

When enhancing ICT product development practices, it is essential to obtain versatile data, while avoiding unnecessary burden on employees. The streamlined process may include all important elements and minimises focus on less important ones. Three first stages, initiation, documents and interviews can be combined to collecting background information. However, combining the beginning requires adequate briefing to ensure participant readiness. Streamlined, integrated beginning is enough to assure that both management and employee viewpoints will be included, and for customising the survey and focus group phases of the process. The experiences of this study suggest that the survey ought to be conducted as web-based to ensure minimised workload for the respondents and process consultant. Also, the end of the process may be streamlined by combining focus group work and drawing conclusions. The focus group ought to generate a documented action plan to ensure concrete development.

\section{Conclusions}

In high-tech, product development projects are typically multi-site, multi-cultural, multi-technical, while product

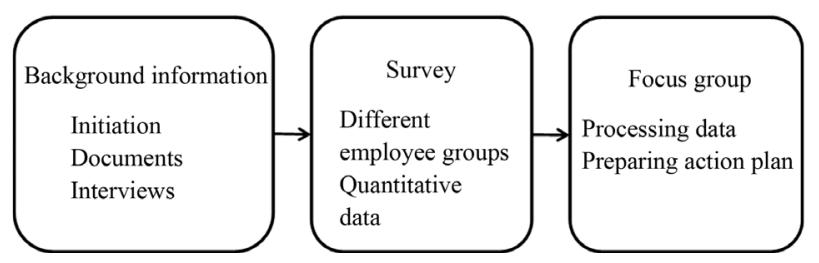

Figure 3. Proposed streamlined process. 
structure is very complex. Consequently, functional communication is a necessity to succeed in business. Communication audits can be used for exploring, examining, monitoring, and evaluating communication. Audits can potentially reveal gaps in the communication process and can provide improvement proposals. The aim of this study was to clarify what kind of process is suitable for assessing the effectiveness of communication in ICT product development.

The results of this study show that it is possible to create a streamlined communication audit process that does not unnecessarily burden the employees while still providing required benefits. This streamlined process comprises of three stages of collecting background information, conducting a survey, and a focus group work for drawing conclusions and preparing an action plan. Background information ensures that both company representatives and auditors are adequately informed and have necessary understanding. The results propose that a customised web-based survey is conducted to minimise the workload. The focus group towards the end of the process proved an efficient way for analysing and translating audit results into tangible action plans. The interviewees see communication audits as one way to develop activities and train personnel.

Managers of high-tech companies can utilise the developed process for enhancing communication in their product development. Communication audit must always be planned case-specifically depending on current interests. Audits should include multiple data gathering and data analysis methods. It is possible to arrange the process so that it requires a limited workload for the involved personnel.

The limitations of this paper include empirical data being only from five cases. Potential topics for future research include applying the proposed process in different companies operating in other industries.

\section{REFERENCES}

[1] D. N. Mallick and R. G. Schroeder, “An Integrated Framework for Measuring Product Development Performance in High Technology Industries," Production and Operations Management, Vol. 14, No. 2, 2005, pp. 142-158. doi:10.1111/j.1937-5956.2005.tb00015.x

[2] G. Barczak, "New Product Strategy, Structure, Process, and Performance in the Telecommunications Industry," Journal of Product Innovation Management, Vol. 12, No. 3, 1995, pp. 224-234. doi:10.1111/1540-5885.1230224

[3] R. Campbell Jr. and M. F. Holmes, "Product Development Processes: Three Vectors of Improvement," Research-Technology Management, Vol. 47, No. 4, 2005, pp. 47-55.

[4] M. Paasivaara, "Communication Practices in Inter-Organisational Product Development,” Doctoral Disserta- tion, Helsinki University of Technology, Espoo, 2005.

[5] M. G. Harvey and D. A. Griffith, “The Role of Globalization, Time Acceleration, and Virtual Global Teams in Fostering Successful Global Product Launches,” Journal of Product Innovation Management, Vol. 24, No. 5, 2007, pp. 486-501. doi:10.1111/j.1540-5885.2007.00265.X

[6] C. P. Killen, R. A. Hunt and E. J. Kleinschmidt, "Managing the New Product Development Project Portfolio: A Review of the Literature and Empirical Evidence," Proceedings of PICMET 2007, Portland International Conference on Managing Engineering and Technology, Portland, 5-9 August, 2007, pp. 1864-1874.

[7] A. Birk and G. Heller, "Challenges for Requirements Engineering and Management in Software Product Line Development," Lecture Notes in Computer Science, Vol. 454, 2007, pp. 300-305. doi:10.1007/978-3-540-73031-6_22

[8] A. C. Edmondson and I. M. Nembhard, "Product Development and Learning in Project Teams: The Challenges Are the Benefits," Journal of Product Innovation Management, Vol. 26, No. 2, 2009, pp. 123-138. doi:10.1111/j.1540-5885.2009.00341.x

[9] F. E. A. van Echtelt, F. Wynstra, A. J. van Weele and G. Duysters, "Managing Supplier Involvement in New Product Development: A Multiple-Case Study,” Journal of Product Innovation Management, Vol. 25, No. 2, 2008, pp. 180-201. doi:10.1111/j.1540-5885.2008.00293.x

[10] O. Hargie and D. Dickson, “Are Important Corporate Policies Understood by Employees? A Tracking Study of Organizational Information Flow," Journal of Communication management, Vol. 11, No. 1, 2007, pp. 9-28.

[11] L. Holtzhausen and L. Fourie, “Employees’ Perceptions of Company Values and Objectives and Employer-Employee Relationships: A Theoretical Model,” Corporate Communications: An International Journal, Vol. 14, No. 3, 2009, pp. 333-344.

[12] R. H. Bartholmé and T. C. Melewar, "Remodelling the Corporate Visual Identity Construct: A Reference to the Sensory and Auditory Dimension," Corporate Communications: An International Journal, Vol. 16, No. 1, 2011, pp. 53-64.

[13] R. Rothwell, "Successful Industrial Innovation: Critical Factors for the 1990s," R\&D Management, Vol. 22, No. 3, 1992, pp. 221-240. doi:10.1111/j.1467-9310.1992.tb00812.x

[14] A. E. Akgün, G. S. Lynn and J. C. Byrne, “Taking the Guesswork out of New Product Development: How Successful High-Tech Companies Get That Way,” Journal of Business Strategy, Vol. 25, No. 4, 2004, pp. 41-46. doi:10.1108/02756660410547395

[15] M. Song and J. Noh, "Best New Product Development and Management Practices in the Korean High-Tech Industry,” Industrial Marketing Management, Vol. 35, No. 3, 2006, pp. 262-278. doi:10.1016/j.indmarman.2005.04.007

[16] R. G. Cooper and E. J. Kleinschmidt, "Winning Businesses in Product Development: The Critical Success Factors,” Research-Technology Management, Vol. 50, No. 


$$
\text { 3, 2007, pp. 52-66. }
$$

[17] J. K. Henderson, "Evaluating Public Relations Effectiveness in a Health Care Setting. The Identification of Communication Assets and Liabilities via a Communication Audit," Journal of Health and Human Services Administration, Vol. 28, No. 2, 2005, pp. 282-322.

[18] C. W. Downs and A. D. Adrian, "Assessing Organizational Communication: Strategic Communication Audits,” The Guilford Press, New York, 2004.

[19] O. Hargie and D. Tourish, “Auditing Organizational Communication. A Handbook of Research, Theory and Practice,” Routledge, New York, 2009.

[20] K. Zwijze-Koning and M. de Jong "Evaluating the Communication Satisfaction Questionnaire as a Communication Audit Tool,” Management Communication Quarterly, Vol. 20, No. 3, 2007, pp. 261-282. doi:10.1177/0893318906295680

[21] M. Vos, "Communication Quality and Added Value: A Measurement Instrument for Municipalities,” Journal of Communication Management, Vol. 13, No. 4, 2009, pp. 362-377. doi:10.1108/13632540911004623

[22] L. Ramsing, "Project Communication in a Strategic Internal Perspective," Corporate Communications: An International Journal, Vol. 14, No. 3, 2009, pp. 345-357. doi:10.1108/13563280910980113

[23] K. Zwijze-Koning and M. de Jong, “Auditing Information Structures in Organizations: A Review of Data Collection Techniques for Network Analysis,” Organizational Research Methods, Vol. 8, No. 4, 2005, pp. 429-453. doi:10.1177/1094428105280120

[24] P. Clampitt, “The Questionnaire Approach,” In: O. Hargie and D. Tourish, Eds., The Handbook of Communication Audits for Organizations, Routledge, London, 2000, pp. 45-65.

[25] D. Dickson, “The Focus Group Approach,” In: O. Hargie and D. Tourish, Eds., The Handbook of Communication Audits for Organizations, Routledge, London, 2000, pp. 85-103.

[26] R. Millar and M. Gallagher, "The Interview Approach,” In: O. Hargie and D. Tourish, Eds., The Handbook of Communication Audits for Organizations, Routledge, London, 2000, pp. 66-84.

[27] D. Dickson, “The Focus Group Approach,” In: O. Hargie and D. Tourish, Eds., Auditing Organizational Communication: A Handbook of Research, Theory and Practice, Routledge, New York, 2009, p. 103.

[28] C. W. Downs and M. D. Hazen, "A Factor Analytic Study of Communication Satisfaction,” Journal of Business Communication, Vol. 14, No. 3, 1977, p. 63. doi:10.1177/002194367701400306

[29] G. M. Goldhaber and P. D. Krivonos, "The ICA Communication Audit: Process, Status, Critique,” Journal of Business Communication, Vol. 15, No. 1, 1977, pp. 41-64. doi:10.1177/002194367701500104

[30] G. M. Goldhaber, "Communication Audits in the Age of the Internet,” Management Communication Quarterly, Vol. 15, No. 3, 2002, pp. 451-457. doi:10.1177/0893318902153007

[31] O. Wiio and M. Helsila, "Auditing Communication in Organizations: A Standard Survey, LTT Communication Audits,” Finnish Journal of Business Economics, Vol. 4, 1974, pp. 305-315.

[32] O. A. Wiio, "Organizational Communication and Its Development,” Helsinki, Viestintäinstituutti, 1977.

[33] K. Zwijze-Koning and M. de Jong, “Auditing Management Practices in Schools: Recurring Communication Problems and Solutions," International Journal of Educational Management, Vol. 23, No. 3, 2009, pp. 227-236. doi:10.1108/09513540910941739

[34] A. Mazzei, "Promoting Active Communication Behaviours through Internal Communication,” Corporate Communications: An International Journal, Vol. 15, No. 3, 2010, pp. 221-234.

[35] S. Wilkinson, "Focus Group Reseach,” Sage Publications Ltd, London, 2004.

[36] R. A. Krueger and M. A. Casey, "Focus Groups: A Practical Guide for Applied Research,” Sage Publications Ltd, London, 2000.

[37] R. Müller, “Communication of Information Technology: Project Sponsors and Managers in Buyer-Seller Relationships,” Universal Publishers, London, 2003.

[38] Construction Industry Institute, “COMPASS: Communications Project Assessment Tool,” 1996.

[39] D. L. Morgan, “The Focus Group Guidebook,” Sage Publications, London, 1998. 


\section{Appendix I. Survey Questionnaire Questions.}

\begin{tabular}{|c|c|c|c|c|c|c|c|}
\hline Module & Question & $2 \mathrm{D}^{1}$ & $\begin{array}{c}\text { Reference: } \\
\text { Downs and } \\
\text { Hazen (1977) }\end{array}$ & COMPASS & $\begin{array}{l}\text { Müller } \\
\text { (2003) }\end{array}$ & $\begin{array}{l}\text { Wiio (1977, } \\
\text { 1974) }\end{array}$ & Interviews \\
\hline \multirow{2}{*}{ A } & 1. In which site is your workplace located? & & & $\mathrm{x}$ & & & $\mathrm{X}$ \\
\hline & 2. Organization you belong to & & & $\mathrm{x}$ & & & $\mathrm{x}$ \\
\hline \multirow{8}{*}{ B } & 1. What is your role in this program? & & $\mathrm{X}$ & & $\mathrm{X}$ & & \\
\hline & 2. What is your role in this project? & & $\mathrm{x}$ & & $\mathrm{x}$ & $\mathrm{x}$ & \\
\hline & $\begin{array}{l}\text { 3. How well do you know the top five formal objectives } \\
\text { of your program? }\end{array}$ & & $\mathrm{x}$ & $\mathrm{x}$ & $\mathrm{x}$ & $\mathrm{x}$ & $\mathrm{x}$ \\
\hline & $\begin{array}{l}\text { 4. How well do you know the top five formal objectives } \\
\text { of your project? }\end{array}$ & & $\mathrm{x}$ & $\mathrm{X}$ & $\mathrm{x}$ & $\mathrm{x}$ & $\mathrm{X}$ \\
\hline & 5. Success of the program & & & $\mathrm{x}$ & & $\mathrm{x}$ & $\mathrm{x}$ \\
\hline & 6. Success of the project & & & $\mathrm{x}$ & & $\mathrm{x}$ & $\mathrm{x}$ \\
\hline & 7. Communicating with persons from other programs & & $\mathrm{X}$ & & & $\mathrm{x}$ & \\
\hline & 8. Communicating with persons from other projects & & $\mathrm{x}$ & & & $\mathrm{x}$ & \\
\hline \multirow{10}{*}{$\mathrm{C}$} & 1. Program communication in general & $\mathrm{x}$ & $\mathrm{x}$ & $\mathrm{x}$ & & $\mathrm{x}$ & \\
\hline & $\begin{array}{l}\text { 3. Communication plan: Is there a communication plan } \\
\text { in the project/program? }\end{array}$ & & & & & & $\mathrm{x}$ \\
\hline & 4. Communication planning & $\mathrm{X}$ & & & & & $\mathrm{X}$ \\
\hline & 5. Understanding what is expected from you & $\mathrm{x}$ & $\mathrm{X}$ & & & $\mathrm{x}$ & \\
\hline & 6. Understanding roles and responsibilities & $\mathrm{x}$ & $\mathrm{x}$ & & & $\mathrm{x}$ & \\
\hline & 7. Introduction to communication methods and tools & $\mathrm{x}$ & $\mathrm{x}$ & $\mathrm{x}$ & & $\mathrm{x}$ & \\
\hline & $\begin{array}{l}\text { 8. Knowing where or from who to get information you } \\
\text { need }\end{array}$ & & $\mathrm{x}$ & $\mathrm{x}$ & & $\mathrm{x}$ & \\
\hline & 9. Access to people with information necessary to you & & $\mathrm{X}$ & $\mathrm{x}$ & & $\mathrm{X}$ & \\
\hline & 10. Access to information necessary to you & & $\mathrm{x}$ & $\mathrm{x}$ & & $\mathrm{x}$ & \\
\hline & 11. Being kept up-to-date with changes & $\mathrm{x}$ & & $\mathrm{x}$ & & $\mathrm{x}$ & \\
\hline \multirow{7}{*}{$\mathrm{D}$} & $\begin{array}{l}\text { 1. How well do you understand how your project af- } \\
\text { fects other projects? }\end{array}$ & & & & & & $\mathrm{X}$ \\
\hline & 2. Communication with other projects & $\mathrm{x}$ & & & & & $\mathrm{X}$ \\
\hline & 4. Communication with other programs & $\mathrm{x}$ & & & & & $\mathrm{x}$ \\
\hline & $\begin{array}{l}\text { 5. Project/program customer: How well do you know } \\
\text { the project/program customer? }\end{array}$ & & $\mathrm{X}$ & & & & $\mathrm{X}$ \\
\hline & 6. Communication with the project/program customer & $\mathrm{x}$ & $\mathrm{X}$ & & & & $\mathrm{X}$ \\
\hline & 7. Communication with external project personnel & & $\mathrm{x}$ & & & & $\mathrm{x}$ \\
\hline & $\begin{array}{l}\text { 8. Communication problems: At what level do you } \\
\text { think communication problems mainly occur? }\end{array}$ & & & $\mathrm{X}$ & & $\mathrm{x}$ & \\
\hline \multirow{13}{*}{$\mathrm{E}$} & $\begin{array}{l}\text { 1. Project follow-up: How important are visual control } \\
\text { practices like schedule at white board? }\end{array}$ & & & & $\mathrm{x}$ & & $\mathrm{x}$ \\
\hline & 2. Document management system & $\mathrm{x}$ & $\mathrm{X}$ & $\mathrm{X}$ & $\mathrm{X}$ & $\mathrm{X}$ & \\
\hline & 3. Program intranet pages & $\mathrm{x}$ & & $\mathrm{x}$ & $\mathrm{x}$ & $\mathrm{x}$ & \\
\hline & 4. Project intranet pages & $\mathrm{x}$ & & $\mathrm{x}$ & $\mathrm{x}$ & $\mathrm{x}$ & \\
\hline & 5. Info email/Project newsletter & $\mathrm{x}$ & & $\mathrm{x}$ & $\mathrm{x}$ & $\mathrm{x}$ & \\
\hline & 6. Project reviews & $\mathrm{x}$ & & $\mathrm{X}$ & $\mathrm{x}$ & $\mathrm{x}$ & \\
\hline & 7. Project meetings & $\mathrm{x}$ & $\mathrm{X}$ & $\mathrm{x}$ & $\mathrm{x}$ & $\mathrm{x}$ & \\
\hline & 8. Project team meetings & $\mathrm{x}$ & $\mathrm{x}$ & $\mathrm{x}$ & $\mathrm{x}$ & $\mathrm{x}$ & \\
\hline & 9. Program info sessions & $\mathrm{x}$ & & $\mathrm{x}$ & $\mathrm{x}$ & $\mathrm{x}$ & \\
\hline & 10. Project info sessions & $\mathrm{x}$ & & $\mathrm{x}$ & $\mathrm{x}$ & $\mathrm{x}$ & \\
\hline & 11. Communication by email & $\mathrm{x}$ & $\mathrm{X}$ & $\mathrm{x}$ & $\mathrm{x}$ & & \\
\hline & 12. Communication by phone & $\mathrm{x}$ & $\mathrm{x}$ & $\mathrm{x}$ & $\mathrm{x}$ & & \\
\hline & 13. Primary information source & & & $\mathrm{x}$ & $\mathrm{x}$ & & $\mathrm{X}$ \\
\hline \multirow{6}{*}{$\mathrm{F}$} & 1. Your experience in project work & & & & & $\mathrm{X}$ & \\
\hline & 2. Communication inside the project team & $\mathrm{X}$ & $\mathrm{X}$ & & & $\mathrm{x}$ & \\
\hline & 3. Communication between teams & $\mathrm{x}$ & $\mathrm{x}$ & & & $\mathrm{x}$ & \\
\hline & $\begin{array}{l}\text { 4. Communication between the team and the project } \\
\text { manager }\end{array}$ & $\mathrm{x}$ & $\mathrm{x}$ & & & $\mathrm{x}$ & \\
\hline & $\begin{array}{l}\text { 5. Communication between the team and the program } \\
\text { manager }\end{array}$ & $\mathrm{x}$ & & & & $\mathrm{x}$ & \\
\hline & 6. Team spirit in the team & $\mathrm{x}$ & & & & $\mathrm{x}$ & \\
\hline
\end{tabular}




\section{Continued}

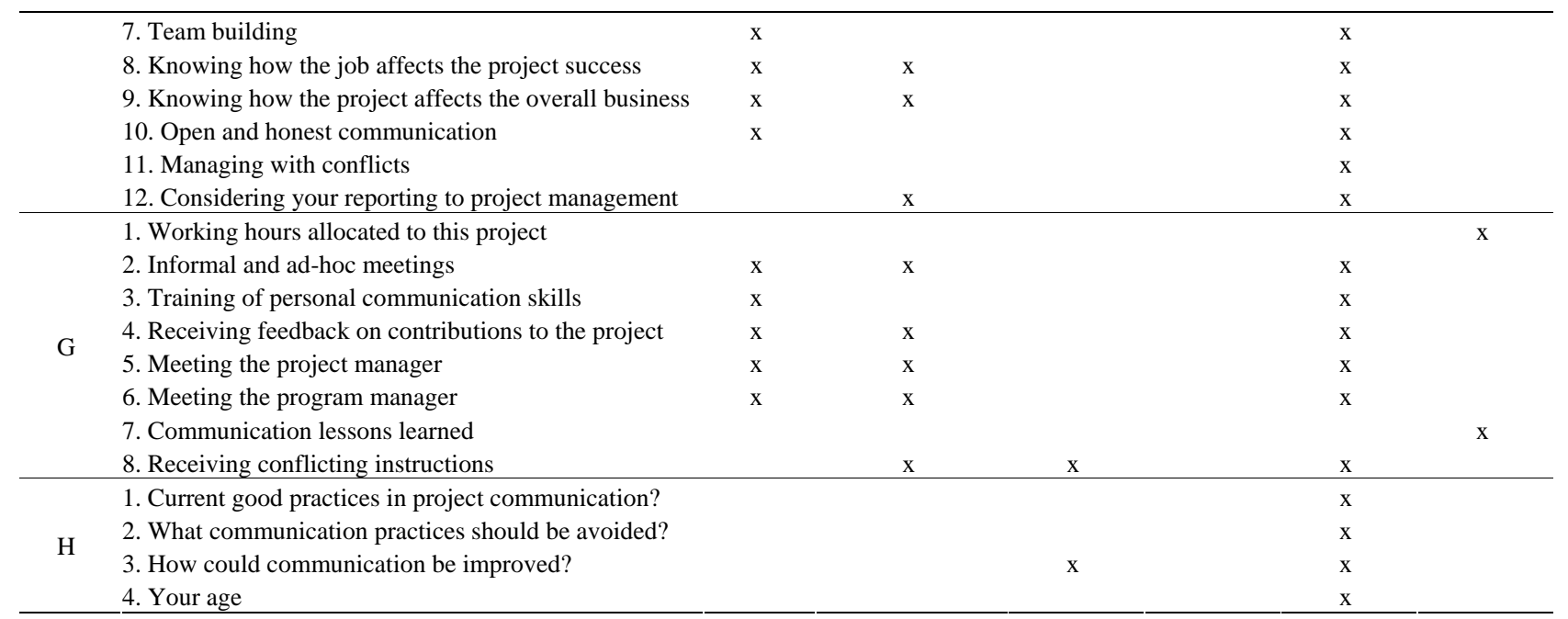

